Сергій Мотика,

Військовий інститут Київського національного університету імені Тараса Шевченка ORCID ID 0000-0001-6423-7697

Леонід Олійник, кандидат педагогічних наук, старший науковий співробітник Національний університет оборони України імені Івана Черняховського ORCID ID 0000-0002-7375-1281

\title{
ЗМІСТ ВИХОВАННЯ ПАТРІОТИЗМУ УЧНІВСЬКОЇ МОЛОДІ В УМОВАХ ВІЙСЬКОВОГО ЛІЦЕЮ
}

У статті розглянуто зміст виховання патріотизму військових ліцеїстів. Окреслено питання виховання патріотизму молоді в Украӥні, провідні ідеї патріотичного виховання y вітчизняній педагогічній теорії та виховній практиці, обтрунтовано актуальність $i$ його особливе значення в сучасному українському суспільстві.

Теоретичний аспект иієї проблеми полягає у висвітленні актуальності, сутності та особливостей виховання патріотизму учнівської молоді в умовах військового ліцею.

Пропонуються напрями перспективних досліджень із зазначеної проблематики.

Ключові слова: патріотизм; патріотичне виховання; любов до Батьківщини; військові ліцеїсти; зміст.

Постановка проблеми. На сучасному етапі розвитку українського суспільства, держави та збройних сил, що характеризується постійним зростанням ролі духовної складової, питання виховання патріотизму, набуваючи особливого значення, стають пріоритетними державними завданнями. Однією з основ захисту суверенітету, територіальної цілісності нашої країни $є$ патріотизм військових ліцеїстів, що грунтується на історичних традиціях сивої давнини.

Сьогодні, як ніколи раніше, спостерігається тенденція підвищення престижу військової служби. Подібні трансформаційні процеси вимагають від людини вироблення власної усталеної громадянської позиції, ставлення до держави як громадянина, патріота. Отже, нині серед громадянських цінностей украй необхідно зміцнювати патріотичні почуття людини, що характеризують іiі ставлення до свого народу й рідної землі, іiі готовність до трудового й героїчного подвигу в ім'я Батьківщини. До того ж важливим для суспільства $\epsilon$ те, що взірцем громадянина-патріота мають бути саме представники учнівської молоді, зокрема військові ліцеїсти. Очевидно, що патріотизм військових ліцеїстів має певні особливості, оскільки це не лише особисте громадянське почуття, а й в подальшому - виконаний військово-професійний обов'язок.

Аналіз останніх досліджень і публікацій. Проблема патріотизму, пізнання його сутності привертали увагу видатних українських мислителів, державних і політичних діячів, представників науки й культури. Це знайшло своє відображення у працях, зокрема, М. Грушевського, А. Макаренка, 
Г. Сковороди, В. Сухомлинського, І. Франка, Т. Шевченка та ін. Вихованню громадянина-патріота велику увагу приділяли Г. Ващенко, I. Огієнко, С. Русова, К. Ушинський та інші українські педагоги.

Нині проблеми виховання патріотизму учнівської молоді стали предметом цілої низки дисертаційних досліджень i наукових праць українських вчених (І. Бех, М. Боришевський, В. Івашковський, В. Каюков Р. Петронговський, Ю. Руденко, О. Сухомлинська, К. Чорна). Важливе значення мають роботи 3 теорії та практики формування патріотизму у військовослужбовців Збройних Сил України (В. Алещенко, А. Афанасьєв, В. Баранівський, В. Дзюба, Я. Зорій, Ю. Красильник, Р. Кутовий, В. Мірошніченко, Л. Олійник, Г. П'янковський), водночас дослідження, присвячені вихованню патріотизму військових ліцеїстів практично відсутні.

Мета статті - обгрунтування змісту виховання патріотизму учнівської молоді в умовах військового ліцею.

Виклад основного матеріалу. Сучасний період державотворення в Україні характеризується складними соціально-економічними, політичними й духовними процесами. У суспільній свідомості, особливо серед молоді, набули поширення байдужість, егоїзм, індивідуалізм, цинізм, немотивована агресивність. Аналогічні тенденції, на жаль, мають місце у військових ліцеях, подальший розвиток яких висуває підвищені вимоги до самосвідомості, мотивації та життєвих настанов ліцеїстів. Відомо, що вони безпосередньо формуються й розвиваються у процесі виховання патріотизму. У зв'язку 3 цим $\epsilon$ очевидною невідкладність вирішення проблем формування у військових ліцеїстів патріотизму як основи консолідації суспільства та зміцнення Збройних Сил України.

Як вважають фахівці, цілі їх виховання, зокрема патріотизму, знаходять своє відбиття у змістовному компоненті процесу виховання військових ліцеїстів, що представляє собою систему ідей, ідеалів, думок, цінностей, основних напрямків виховного впливу $[1,157]$. Цей компонент має відповісти на такі запитання:

- на яких ідеалах і цінностях слід виховувати учнівську молодь в умовах військового ліцею?

- що вони повинні опанувати у процесі виховання патріотизму?

Під категорією «зміст виховання патріотизму учнівської молоді в умовах військового ліцею» треба мати на увазі два аспекти: по-перше, державні вимоги до виховання загалом і виховання патріотизму зокрема; подруге, специфіку військового виховання, що викладена в Концепції виховної роботи у ЗС та інших військових формуваннях України [2], Концепції гуманітарного та соціального розвитку у ЗС України [3] й інших документах.

Формування моральних якостей особистості, правової культури (усвідомлення верховенства права, повага до державних символів), готовності до виконання конституційних обов'язків, усвідомлення національної ідентичності, а також утвердження національних i загальнолюдських цінностей складають мету виховання патріотизму молоді. 
Однією з його складових $є$ виховання патріотизму учнівської молоді в умовах військового ліцею, спрямоване на розвиток особистості на основі бойових традицій свого народу, формування готовності до захисту Вітчизни, а також мотивації до військової служби, фізичної та психологічної готовності до проходження іiі у збройних силах, підготовку до оволодіння військовими професіями.

Виховання патріотизму учнівської молоді в умовах військового ліцею проводиться шляхом допризовної підготовки в середніх загальноосвітніх навчальних закладах мережею військових ліцеїв, зокрема Київським військовим ліцеєм імені Івана Богуна й Військово-морським ліцеєм, а також ліцеями 3 посиленою військово-фізичною підготовкою. Їх діяльність регулюється наказом Міністерства оборони України від 17.07.2003 р. № 1087 «Про затвердження Положення про військовий ліцей», постановою Кабінету Міністрів України від 28.04.1999 № 717 «Про затвердження Положення про ліцей з посиленою військово-фізичною підготовкою» тощо.

Військовий ліцей є загальноосвітнім навчальним закладом із військовопрофесійною спрямованістю навчання та допрофесійною підготовкою, що передбачає проведення поглибленої допризовної та посиленої фізичної підготовки й виховання в юнаків готовності до військової служби, а також можливість здобуття первинних військових знань і навичок, необхідних для подальшого навчання у вищих військових навчальних закладах та вищих навчальних закладах, що мають військові навчальні підрозділи.

Сьогодні завдяки висвітленню у засобах масової інформації основних віх діяльності Збройних Сил України, більшої відкритості Міністерства оборони України спостерігається істотне підвищення зацікавленості молоді військовими професіями [5]. Проте виховання патріотизму учнівської молоді потребує системності та послідовності, зокрема удосконалення нормативноправової бази. За часи незалежності в Україні було розроблено низку концепцій патріотичного виховання, а саме: Концепція національної системи виховання (1996р.), Концепція національно-патріотичного виховання (2009 р.), Концепція виховання ліцеїстів військових ліцеїв (2010 р.), Концепція громадянської освіти та виховання в Україні (2012 р.), Концепція Загальнодержавної цільової програми патріотичного виховання громадян на 2013-2017 рр. Проте жодну з них не було втілено в життя через відмінності в поглядах правлячих еліт на ідеологію й напрями розвитку освіти та нерозробленість державних програм із їх реалізації.

Наразі прийнято нову Концепцію національно-патріотичного виховання дітей та молоді, принциповою відмінністю якої є конкретний план заходів

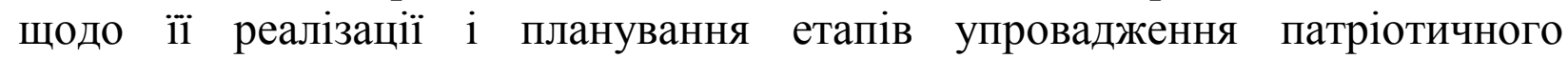
виховання. Особлива увага в ній зосереджується на здійсненні військовопатріотичного виховання як необхідної умови національної безпеки [6].

Одним зі шляхів реалізації виховання патріотизму є участь молоді в заходах патріотичного спрямування, зокрема, присвячених загальнодержавним святам, героїзації захисників незалежності України в 
сучасних умовах та минулому [7]. У загальноосвітніх навчальних закладах здійснено низку заходів, ініційованих Міністерством освіти і науки України спільно з Міністерством оборони України, що мали на меті формування в дітей та молоді національної ідентичності на прикладах мужності військовослужбовців Збройних Сил України [7]. Крім того проведення спортивних заходів і військово-патріотичних ігор (наприклад «Джура», «Кадет») сприяє пропагуванню здорового способу життя та підвищенню загального рівня фізичної підготовки молоді, а також зміцненню міжрегіональних зв'язків дітей і юнацтва.

Виховання патріотизму школярів загалом та учнівської молоді в умовах військового ліцею зокрема є питанням державного значення, адже пов' язане 3 національною безпекою. Особлива увага має бути зосереджена на його реалізації саме в системі середньої освіти, військових ліцеїв, сприяючи усвідомленню молоддю ролі збройних сил і значущості військової професії в сучасних умовах.

Під час визначення змісту виховання патріотизму учнівської молоді в умовах військового ліцею необхідно також мати на увазі їх загальний освітній рівень, фізичний і морально-психічний стан, індивідуально-психічні особливості, майбутню військово-професійну діяльність.

Добір змісту виховання патріотизму учнівської молоді в умовах військового ліцею має враховувати такі вимоги:

- відповідати соціальному замовленню українського суспільства, вимогам, що висуваються до виховання патріотизму учнівської молоді в умовах військового ліцею;

- бути спрямованим на здійснення головної мети виховання патріотизму - формування й розвитку патріотично налаштованої, всебічно й гармонійно розвиненої особистості військового ліцеїста - громадянина та патріота України;

- спиратися на сучасні загальнолюдські, національні, військові цінності, ідеали й формувати патріотичний світогляд;

- відповідати духовним і фізичним можливостям вихованців, сприяти їх активізації на самовиховання;

- сприяти єдності їх виховання, навчання, розвитку, психологічної підготовки та самовдосконалення.

Зміст виховання патріотизму учнівської молоді в умовах військового ліцею $\epsilon$ важливим елементом процесу виховання військовослужбовців і відображається в його основних напрямах: військово-професійне виховання, національне виховання, моральне виховання, розумове виховання, естетичне виховання, соціально-правове виховання, родинно-сімейне виховання, фізичне виховання.

Виховання патріотизму учнівської молоді в умовах військового ліцею, як і громадян України в цілому, по суті, не існує ізольовано від вищеназваних напрямів виховання. Це інтегруючий напрям, що органічно поєднує в собі «ціннісні зрізи» основних напрямів виховання: військово-професійного, 
національного, морального, родинно-сімейного, естетичного, соціальноправового, екологічного, фізичного виховання тощо. Тобто виховання патріотизму учнівської молоді в умовах військового ліцею, зокрема його зміст, можна вважати ціннісним компонентом будь-якого напряму військового виховання.

Необхідно враховувати, що зміст виховання патріотизму учнівської молоді в умовах військового ліцею визначається не лише цілеспрямовано організованим виховним процесом у військовому ліцеї, але всім спектром моральних і психологічних впливів на особистість ліцеїста. Тому ефективність виховного процесу значною мірою залежатиме від узгодженості організаційної та педагогічної діяльності всіх суб'єктів виховання.

У процесі виховання патріотизму учнівської молоді в умовах військового ліцею формується патріотична свідомість як результат відображення в їх свідомості «атрибутів Вітчизни» та ЗС України, що є сукупністю ціннісних елементів будь-якої форми суспільної свідомості. Її можна розглядати як складну систему ідей і поглядів, патріотичних та бойових традицій i принципів поведінки, почуттів та настроїв народу України, соціальних груп й індивідів, які слугують ідеальними збуджувальними мотивами дій, спрямованих на громадянський розвиток особистості та захист Вітчизни. Сформованість патріотичної свідомості характеризує сутність особистісних перетворень у психіці військового ліцеїста, що відбуваються у процесі виховання патріотизму.

Ураховуючи погляди фахівців, головним результатом вихованості громадянина-патріота - військового ліцеїста можна вважати розвиненість у нього комплексу особистісних якостей. На основі аналізу існуючих наукових робіт ми визначили особистісні якості й риси характеру військових ліцеїстів, що $\epsilon$ «..основою специфічного способу мислення та спонукальною силою повсякденних дій, вчинків, поведінки» [4].

Основними завданнями виховання патріотизму учнівської молоді в умовах військового ліцею є формування в молодих громадян України високої самосвідомості й патріотизму, активної життєвої позиції, національної гідності, готовності до виконання конституційного та громадянського обов'язку щодо захисту національних інтересів України. Військове виховання здійснюється протягом усього освітнього процесу ліцеїстів. Ступінь їх вихованості визначається також рівнем загальновійськової підготовки, що вимагає великих вольових зусиль, самодисципліни, організованості, витривалості, фізичної й моральної напруги. Це формує у військових ліцеїстів морально-психологічні якості, в основі яких лежить воля.

Зміст виховання патріотизму учнівської молоді в умовах військового ліцею спрямовується на іï залучення до позакласної діяльності, що сприяє задоволенню потреб військових ліцеїстів у формуванні патріотичного мислення, патріотичної свідомості, розвитку інтелекту особистості для активної громадянської позиції та реалізації іiі у практичній діяльності. 
Виховання патріотизму учнівської молоді в умовах військового ліцею це, передусім, комплекс системних заходів спрямованих на:

- виховання в ліцеїстів свідомого виконання свого громадянського обов'язку, вірності Військовій присязі, формування внутрішньої необхідності суворого виконання військових атрибутів, наказів командирів, якісного навчання;

- розвиток духовної та психологічної готовності майбутніх воїнів захищати свою Батьківщину;

- виховання морально-бойових якостей, активної громадянської позиції, упевненої реакції на бойові ситуації, готовності до суворих іспитів і самопожертви в ім'я України та її народу;

- формування у військових ліцеїстів провідних мотивів до оволодіння військовими знаннями, високого рівня фізичної підготовки й витривалості;

- підвищення престижу військової служби у лавах Збройних Сил України, формування бажання в них навчатися у вищих військових навчальних закладах;

- розвиток у військових ліцеїстів загальнолюдських цінностей, національної гордості, морально-психологічних якостей громадянинапатріота;

- удосконалення організації, форм і методів виховання патріотизму учнівської молоді в умовах військового ліцею.

На сучасному складному етапі розвитку українського суспільства, держави та Збройних Сил України проблема виховання патріотизму військових ліцеїстів набуває особливого значення. Це викликано суттєвим підвищенням ролі духовного компонента у функціонуванні військових ліцеїв, неможливістю активізації позитивно спрямованої соціальної активності військових ліцеїстів без кардинального підвищення рівня їх патріотичної вихованості.

Висновки та перспективи подальших досліджень. Таким чином, виховання патріотизму учнівської молоді в умовах військового ліцею спрямовано на формування у військових ліцеїстів патріотичної свідомості, самосвідомості й комплексу професійних та особистісних якостей (моральнополітичних, громадянських, військово-професійних, соціальнопсихологічних, психічних, фізичних). Найсуттєвішим критерієм їх сформованості ми вважаємо стійку готовність майбутніх воїнів до ефективної військово-професійної діяльності, сумлінного виконання військового обов'язку, прагнення практичними справами зміцнювати Українську державу та її збройні сили.

Отже, під поняттям «зміст виховання патріотизму учнівської молоді в умовах військового ліцею» можна розуміти систему духовних, патріотичних, військово-професійних знань, навичок, умінь, норм і правил поведінки, оволодіння якими забезпечує формування гармонійно розвиненої, суспільно активної особистості військового ліцеїста - громадянина-патріота України, його прилучення до загальнолюдських, національних, військових цінностей, освоєння ним світоглядних, морально-етичних та інших властивостей, формування їх індивідуальності й підготовку до захисту Батьківщини. 
Перспективами подальшого дослідження $\epsilon$ визначення технології виховання патріотизму учнівської молоді в умовах військового ліцею.

\section{ЛІТЕРАТУРА}

1. Військове виховання: історія, теорія та методика: навч. посіб. / За ред. В. В. Ягупова. - К.: “Graphic\&Design”, 2002. - 306 c.

2. Концепція виховної роботи у Збройних силах та інших військових формуваннях України, затверджена Указом Президента України від 4 вересня 1998 року № 981/98 // Зб. указів Президента України. - К.: Політвидав, 1998. - Вип. 3. C. 203-207.

3. Концепція гуманітарного і соціального розвитку у Збройних Силах України : Затверджена Указом Президента України від 12 січня 2004 року № 28/2004 // Народна армія. - 2004. - 4 лютого. - С. 1-2.

4. Косарєва Н. І. Особливості громадянського виховання студентської молоді // Громадянське виховання студентської молоді в умовах трансформації суспільства: Зб. наук. ст.: За мат. Всеукр. наук.-практ. сем. / М. П. Лукашевич та ін. (ред.). - Черкаси, 1998. - C. 61-69.

5. Молодь обирає військо // Народна армія. - 2015. - №70 (5405). - С. 6

6. Наказ Міністерства освіти і науки України від 16 червня 2015 № 641 "Про затвердження Концепції національно-патріотичного виховання дітей і молоді, Заходів щодо реалізації Концепції національно-патріотичного виховання дітей і молоді та методичних рекомендацій щодо національно-патріотичного виховання у загальноосвітніх навчальних закладах" [Електронний ресурс]. - Режим доступу: http://old.mon.gov.ua/ru/aboutministry/normative/4068-

7. Указ Президента України від 12 червня 2015 № 334 "Про заходи щодо поліпшення національно-патріотичного виховання дітей та молоді” // Офіційний вісник Президента України від 18.06.2015 р., № 14, стор. 45, стаття 971.

\section{REFERENCES}

1. Viys'kove vykhovannya: istoriya, teoriya ta metodyka: Navch. posib. [Military education: history, theory and methodology: Teaching. manual] / Za red. V. V. Yahupova. - K.: "Graphic\&Design", 2002. - 306 s.

2. Kontseptsiya vykhovnoyi roboty u Zbroynykh sylakh ta inshykh viys'kovykh formuvannyakh Ukrayiny, zatverdzhena Ukazom Prezydenta Ukrayiny vid 4 veresnya 1998 roku \# 981/98 [The concept of educational work in the Armed Forces and other military formations of Ukraine, approved by the Decree of the President of Ukraine of September 4, 1998, No. 981/98] // Zb. ukaziv Prezydenta Ukrayiny. - K. : Politvydav, 1998. - Vyp. 3. - S. 203-207.

3. Kontseptsiya humanitarnoho i sotsial'noho rozvytku u Zbroynykh Sylakh Ukrayiny : Zatverdzhena Ukazom Prezydenta Ukrayiny vid 12 sichnya 2004 roku \# 28/2004 [Concept of humanitarian and social development in the Armed Forces of Ukraine: Approved by the Decree of the President of Ukraine dated January 12, 2004 No. 28/2004] // Narodna armiya. - 2004. 4 lyutoho. - S. $1-2$.

4. Kosaryeva N. I. Osoblyvosti hromadyans'koho vykhovannya student-s'koyi molodi // Hromadyans'ke vykhovannya student-s'koyi molodi $\mathrm{v}$ umovakh transformatsiyi suspil'stva: Zb. nauk. st.: Za mat. Vseukr. nauk.-prakt. sem. [Features of civic education of student youth // Civic education of student youth in conditions of transformation of society: $\mathrm{Zb}$. sciences st .: behind the mat. Allukr science-practice this] / M.P. Lukashevych ta in. (red.). - Cherkasy, 1998. - S. 61-69.

5. Molod' obyraye viys'ko [Youth chooses an army] // Narodna armiya. - 2015. - \#70 (5405). - S. 6

6. Nakaz Ministerstva osvity i nauky Ukrayiny vid 16 chervnya 2015 \# 641 "Pro zatverdzhennya Kontseptsiyi natsional'no-patriotychnoho vykhovannya ditey i molodi, 
Zakhodiv shchodo realizatsiyi Kontseptsiyi natsional'no-patriotychnoho vykhovannya ditey i molodi ta metodychnykh rekomendatsiy shchodo natsional'no-patriotychnoho vykhovannya y zahal'noosvitnikh navchal'nykh zakladakh" [Elektronnyy resurs]. [Order of the Ministry of Education and Science of Ukraine dated June 16, 2015 No. 641 "On Approval of the Concept of National Patriotic Education of Children and Youth, Measures to Implement the Concept of National Patriotic Education of Children and Youth and Methodological Recommendations on National Patriotic Education in General Educational Institutions" [Electronic resource]] Rezhym dostupu: http://old.mon.gov.ua/ru/aboutministry/normative/4068-

7. Ukaz Prezydenta Ukrayiny vid 12 chervnya 2015 \# 334 "Pro zakhody shchodo polipshennya natsional'no-patriotychnoho vykhovannya ditey ta molodi" [Decree of the President of Ukraine dated June 12, 2015 No. 334 "On Measures to Improve the National Patriotic Education of Children and Youth"] // Ofitsiynyy visnyk Prezydenta Ukrayiny vid 18.06.2015 r., \# 14, stor. 45, stattya 971.

\section{PЕЗЮМЕ}

Сергей Мотыка,

Военный институт Киевского национального университета имени Тараса Шевченко

Леонид Олейник, кандидат педагогических наук, старший научый сотрудник Национальный университет обороны Украины имени Ивана Черняховского

\section{Содержание воспитания патриотизма ученической молодежи в условиях военного лищея}

В статье рассмотрено содержание воспитания патриотизма военных лищеистов. Очерчень вопрос воспитания патриотизма молодежи в Украине, ведущие идеи патриотического воспитания в отечественной педагогической теории и воспитательной практике, обосновано актуальность и значение в современном украинском обществе. Теоретический аспект этой проблемь определяется актуальностью, сущностью и особенностями воспитания ученической молодежи в условиях военного лицея. Предлагаются направления перспективных исследований с заявленной проблематики.

Ключевые слова: патриотизм; патриотическое воспитание; любовь к Родине; военные лицеистын; содержание.

\section{SUMMARY \\ Serhii Motyka, Military Institute of Taras Shevchenko National University of Kyiv \\ Leonid Oliynyk, candidate of pedagogical sciences, senior research fellow \\ National Defence University of Ukraine named after I. Cherniahovskyi}

The content of patriotic education among military lyceum students

Introduction. The article considers the content of patriotic education among military lyceum students. The issues of patriotic education of youth in Ukraine, and the leading ideas of patriotic education in the national pedagogical theory and educational practice have been considered. The relevance and its special significance in the modern Ukrainian society have been substantiated. The directions for the perspective research of the mentioned challenge have been offered.The theoretical aspect of this issue is to highlight the relevance, essence and peculiarities of patriotic education among military lyceum students. 
Purpose. Taking into account the lack of scientific development of this problem, the article aims to substantiate the content of upbringing patriotism of student youth in conditions of military lyceum

Methods In determining the content of upbringing of patriotism, young students studying in a military environment use the theoretical methods for assessing the formation of patriotism of students in the conditions of military lyceum: general educational level, physical and psychological state, individual psychic features, future military-professional activities.

Results. At the present complex stage of development of the Ukrainian society, the state and the Armed Forces of Ukraine, the issues of patriotic education among military lyceum students are of a particular importance. This is due to a significant increase in the role of the spiritual component in the functioning of military lyceums, the impossibility of activating the positively directed social activity of military lyceum students without radical improvements of the level of patriotic education.

The notion of "the content of patriotic education among military lyceum students" may mean the system of spiritual, patriotic, and military-professional knowledge, skills, abilities, norms and rules of conduct, the mastery of which ensures the formation of a harmoniously developed, socially active person of military lyceum student - a citizen- the patriot of Ukraine, his attachment to universal, national and military values, the development of his philosophical, moral and ethical and other properties, the formation of individuality and readiness to protect the Motherland. The education of patriotism among students in the military lyceum is primarily a complex of systemic measures aimed at:

the upbringing of military lyceum students by the conscious fulfillment of their civil duty, loyalty to the Military oath, the formation of the internal necessity of strict implementation of military attributes, orders of commanders, qualitative training;

the formation of the spiritual and psychological readiness of military lyceum students future warriors, with the weapon in their hands to protect their homeland;

education of moral and combat qualities, active civilian stance, confident reaction to combat situations, readiness for harsh exams and self-sacrifice in the name of Ukraine and its people;

formation of leading motives for military lyceum students to master military knowledge, high level of physical fitness and endurance;

increase the prestige of military service in the ranks of the Armed Forces of Ukraine, the formation of the desire of military lyceum students to study in higher military educational institutions;

development of universal human values in the military lyceum students, national pride, moral and psychological qualities of a patriotic citizen;

perfection of the organization, forms and methods of education of patriotism of studying youth in the conditions of military lyceum.

Originality. The scientific novelty and practical significance of the research results is determined by a significant increase in the role of the spiritual component in the functioning of military lyceums, the impossibility of activating the positively directed social activity of military lyceum students without dramatically increasing the level of their patriotic upbringing.

Conclusion. Thus, patriotic education among military lyceum students is aimed at the formation of patriotic consciousness, self-consciousness and the corresponding complex of professional and personal qualities (moral-political, civilian, military-professional, socialpsychological, mental, physical) in military lyceum students. The most significant criterion for their formation is the firm commitment of future warriors to effective military-professional activities, the faithful fulfillment of military duty, and the desire to strengthen the Ukrainian state and its armed forces by practical actions.

Prospects for further research on the definition of technology for the upbringing of the patriotism of young students in the conditions of the military lyceum.

Key words: patriotism; patriotic education; love of the Motherland; military lyceum students; content. 